\title{
PAI-1 Expression Is Required for HDACi-Induced Proliferative Arrest in ras-Transformed Renal Epithelial Cells
}

\author{
Stephen P. Higgins, Craig E. Higgins, and Paul J. Higgins \\ Center for Cell Biology and Cancer Research, Albany Medical College (MC-165), Albany, NY 12208, USA \\ Correspondence should be addressed to Paul J. Higgins, higginp@mail.amc.edu
}

Received 26 March 2011; Accepted 25 June 2011

Academic Editor: J. Chloe Bulinski

Copyright (๑) 2011 Stephen P. Higgins et al. This is an open access article distributed under the Creative Commons Attribution License, which permits unrestricted use, distribution, and reproduction in any medium, provided the original work is properly cited.

\begin{abstract}
Malignant transformation of mammalian cells with ras family oncogenes results in dramatic changes in cellular architecture and growth traits. The generation of flat revertants of v-K-ras-transformed renal cells by exposure to the histone deacetylase inhibitor sodium butyrate $(\mathrm{NaB})$ was previously found to be dependent on transcriptional activation of the PAI-1 (SERPINE1) gene (encoding the type-1 inhibitor of urokinase and tissue-type plasminogen activators). NaB-initiated PAI-1 expression preceded induced cell spreading and entry into $\mathrm{G}_{1}$ arrest. To assess the relevance of PAI-1 induction to growth arrest in this cell system more critically, two complementary approaches were used. The addition of a stable, long half-life, recombinant PAI-1 mutant to PAI-1-deficient v-K-ras-/c-Ha-ras-transformants or to PAI-1 functionally null, NaB-resistant, 4HH cells (engineered by antisense knockdown of PAI-1 mRNA transcripts) resulted in marked cytostasis in the absence of NaB. The transfection of ras-transformed cells with the Rc/CMVPAI expression construct, moreover, significantly elevated constitutive PAI-1 synthesis (10- to 20-fold) with a concomitant reduction in proliferative rate. These data suggest that high-level PAI-1 expression suppresses growth of chronic ras-oncogene transformed cells and is likely a major cytostatic effector of $\mathrm{NaB}$ exposure.
\end{abstract}

\section{Introduction}

Histone acetyltransferases (HATs) transfer acetyl groups from acetyl CoA to specific lysine residues in the amino terminal histone "tails" to form $\varepsilon$-N-acetyl lysine promoting an "open" or relaxed chromatin structure. Several transcriptional coactivators, including $\mathrm{CBP} / \mathrm{p} 300$ and SRC, have intrinsic HAT activity $[1,2]$. Histone deacetylases (HDACs), in contrast, catalyze the removal of acetyl groups on target lysines $[3,4]$ creating a condensed, transcriptionally repressed, chromatin organization [5]. Of the various HDAC inhibitors (HDACi), several exhibit more or less specificity for individual members of the four classes (I-VI) of human HDACs $[6,7]$.

A major mode of action of HDACi (i.e., the transcription-dependent mechanism) [5] affects gene reprogramming as a consequence of HDACi type, concentration, and duration of exposure $[8,9]$. Recent estimates place the number of HDACi-impacted genes at $2-10 \%$ of the total expressed repertoire, several of which negatively regulate cell cycle progression [10-13] such as $\mathrm{p} 21^{\mathrm{WAF} 1 / \mathrm{CIP} 1}$ and plasminogen activator inhibitor type-1 (PAI-1; SERPINE1) [14-21]. PAI-1 is particularly relevant in this context as this SERPIN complexes with both urokinase (uPA) and tissue-type (tPA) plasminogen activators to limit pericellular plasmin generation effectively attenuating uPA-/plasmin-dependent growth factor activation and cellular proliferative responses $[22,23]$. PAI- 1 , in fact, is both necessary and sufficient for p53-dependent growth arrest [23-26] and required for TGF- $\beta 1$-mediated antiproliferative effects in human keratinocytes and mouse embryo fibroblasts [27]. Activated ras or raf oncogenes trigger the initiation of a senescence-like growth arrest program, with induction of PAI-1, in several cell types [28-31]. At least some cells transformed as a consequence of chronic oncogenic ras expression, and that escape ras-induced senescence can also undergo proliferative arrest upon exposure to certain HDACi (e.g., sodium butyrate; $\mathrm{NaB}$ ) with concomitant high-level PAI-1 induction $[16,17,32]$. It is not known, however, if HDACi-associated growth inhibition of immortalized ras-transformants, like 
entrance of normal cells into replicative senescence [23], also requires PAI-1-induction.

This paper details the involvement of PAI-1 expression during HDACi-induced growth restriction in several well-

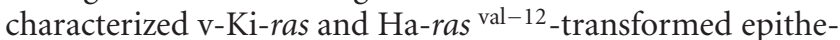
lial cell lines $[15,16]$. $\mathrm{NaB}$ was selected for this study as this HDACi is a potent stimulator of PAI-1 expression [14, $20]$ and cytostasis [16] in ras-transformed renal cells. NaBmediated growth inhibition was not evident in PAI-1 knockdown (i.e., anti-sense) cells, but the HDACi-dependent proliferative block could be rescued by vector-driven PAI-1 overexpression.

\section{Materials and Methods}

2.1. Culture Conditions and Engineered Cells. The various ras-transformed renal epithelial cell lines used in this study $[15,16]$ grow in serum-free DMEM (at least over the short time frame used in this study; 3-5 days) facilitating assessments of the proliferation-modulating effects of $\mathrm{NaB}(1-10 \mathrm{mM})$ and exogenous PAI-1 (0.02-100 nM stable mutant $14-1 \mathrm{~B}, t_{1 / 2}=145$ hours; N150H, K154T, Q319L, M354I) [33] in both the presence and absence of FBS. The derivation of the PAI-1 functionally null knockdown (PAI- ${ }^{\mathrm{KD}}$ ) $4 \mathrm{HH}$ cell line by transfection of a $2.6 \mathrm{~kb}$ rat PAI-1 EcoR1/HindIII cDNA fragment (representing nucleotides -118 to +2572 ) cloned in anti-sense orientation (Rc/CMVIAP) has been described [34, 35]. v-rastransformed cells were also transfected with the Rc/CMVPAI sense vector to initiate high-level PAI-1 expression in the absence of $\mathrm{NaB}$ or with the empty Rc/CMV construct [32]. Coupled in vitro transcription/translation assay confirmed that a full-length immunoreactive PAI-1 protein was synthesized using the Rc/CMVPAI vector as a template [35]. In some cases, Rc/CMVPAI transfectants were selected with G418 [32]. Cloning strategy and cell line derivation are detailed in the text. c-Ha-ras oncogene-expressing human HaCaT II-4 keratinocytes were described previously [33, 36] as were the PAI-1-deficient and reconstituted renal cell lines [35].

2.2. Northern Blotting. Cytoplasmic RNA was separated by electrophoresis on denaturing $1 \%$ agarose/2.2 $\mathrm{M}$ formaldehyde gels, transferred to nitrocellulose and blots hybridized with a ${ }^{32} \mathrm{P}$-labeled EcoRI-HindIII fragment of rat PAI- 1 cDNA (specific activity $1-2 \times 10^{8} \mathrm{cpm} / \mu \mathrm{g}$ DNA) for $48 \mathrm{hr}$ at $4^{\circ} \mathrm{C}$. The recombinant pBluescript (SK(-) phagemid pRPAISS1-3, containing a 3.0-kb EcoRI/SstII-flanked cDNA insert encoding PAI-1, was used for isolation of the pRPAImr1-4 probe used for hybridization. Briefly, pRPAISS1-3 was digested with EcoRI/Hind III at $37^{\circ} \mathrm{C}$ for $1 \mathrm{hr}$ and fragments separated in $1 \%$ agarose gels. After staining with ethidium bromide, bands representing the PAI-1 cDNA insert were excised and electroeluted. This insert fragment (pRPAImr1-4) was labeled with ${ }^{32} \mathrm{P}-\mathrm{dCTP}$ by random priming. Following hybridization, membranes were washed sequentially for 20 minutes each in 2 x SSC/0.1\% SDS (twice) and then in $1 \mathrm{x} \mathrm{SSC} / 0.1 \%$ SDS, all at $55^{\circ} \mathrm{C}$.
2.3. Extraction of Metabolically Labeled Cells and Gel Electrophoresis. Growth media (in 35-mm diameter cultures) were aspirated, cells washed twice with HBSS and $1 \mathrm{~mL}$ of labeling medium (FBS- and methionine-free RPMI 1640 medium containing $50 \mu \mathrm{Ci}{ }^{35} \mathrm{~S}$-methionine (specific activity = $1100 \mathrm{Ci} / \mathrm{mmol}$ ) added to each culture. At the end of a $6 \mathrm{hr}$ labeling period, the substrate adherent-enriched (SAP) cellular fraction was collected, clarified at $13,000 \times \mathrm{g}$, and solubilized in lysis buffer (9.8 M urea, 2\% Nonidet P-40, $2 \%$ ampholytes, and $100 \mathrm{~mm}$ dithiothreitol) [37]. 1-D gel separations were as detailed previously [38]. For 2-D gel electrophoresis, $50,000 \mathrm{cpm}{ }^{35} \mathrm{~S}$-methionine-labeled protein were loaded onto prerun $1.5 \mathrm{~mm}$ diameter tube gels $(9.1 \mathrm{M}$ urea, 2\% Nonidet P-40, 6\% pH 5-7 ampholytes, 1.2\% pH 310 ampholytes, $4 \%$ acrylamide/bisacrylamide for isoelectric focusing (IEF) for $18 \mathrm{hr}$ prior to separation on SDS-10\% acrylamide slab gels [39]. Individual protein spots were mapped and quantitated with a Bio-Image Investigator 2-D Electrophoresis Analysis system interfaced to a SUN SPARC workstation [40].

\section{Results}

3.1. PAI-1 Induction in v-ras-Transformed Renal Cells upon Exposure to the HDACi NaB. Limited expression profiling previously indicated that PAI-1 was among the most abundant of the NaB-upregulated genes in ras-transformed renal epithelial cells $[14,15]$ consistent with microarray and bioinformatic analyses of genetic networks responsive to $\mathrm{NaB}$ in colonic epithelial cells [20]. 1-D electrophoresis (Figure 1(a)), northern blotting (Figure 1(b)), and 2-D proteomic mapping (Figure 1(c)), moreover, confirmed a significant and rather selective PAI- 1 induction in NaB-stimulated $\mathrm{v}$-ras-transformants (involving both the $50-\mathrm{kD}$ and mature 52-kD glycosylated PAI-1 species), using 1-D/2-D mobility and immunochemical identification criteria established previously $[16,38,41]$, relative to nondetectable PAI-1 levels in control v-ras populations. PAI-1 upregulation correlated with a prominent $\mathrm{NaB}$-associated $\mathrm{G}_{1}$ arrest increased cell size (Figure 2) and concentration-dependent proliferative inhibition resulting in a $63 \%$ (Figure $3(\mathrm{a})$ ) and $48 \%$ (Figure $3(\mathrm{~b})$ ) decrease in population density in serum-free and $10 \%$ serum-supplemented medium, respectively (summarized in Figure 4). Collectively, these findings (Figures 1 and 4) are consistent with the conclusion that $\mathrm{v}$-ras-transformants that escape ras oncogene-initiated cellular senescence [29, 42, 43] are essentially PAI-1 null.

3.2. Growth Arrest in ras-Transformants Is Restored by Exogenous Exposure to a Long Half-Life PAI-1 Mutant or by VectorDriven Reconstitution of PAI-1 Expression. Since targeted suppression of PAI-1 leads to bypass of both replicative senescence and TGF- $\beta$-induced growth arrest $[23,27]$, it was important to determine if exogenously-delivered PAI1 could similarly regulate the proliferative response of PAI1-deficient ras transformants in the absence of $\mathrm{NaB}$. The addition of a long half-life recombinant PAI-1 mutant (PAI1 14-1B) effectively suppressed growth of v-ras-transformed 


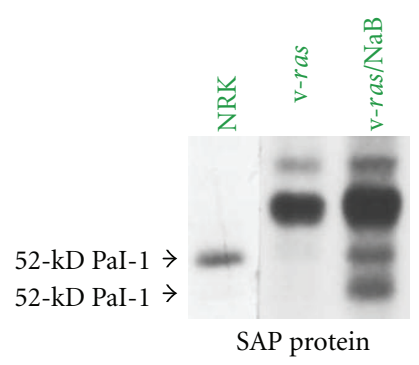

(a)

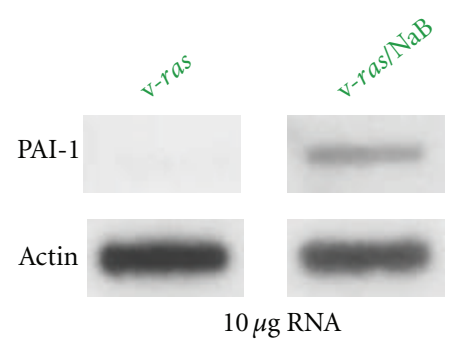

(b)

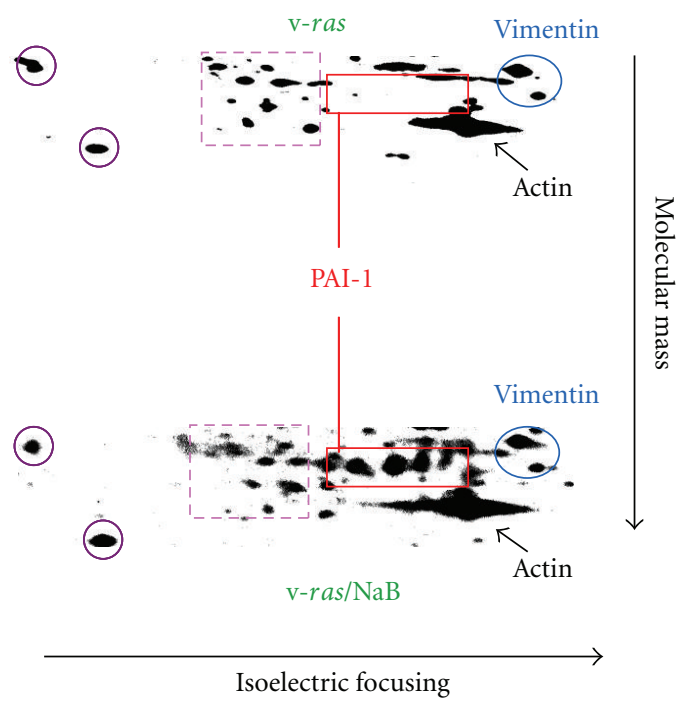

(c)

FIGURE 1: Electrophoresis of the ${ }^{35} \mathrm{~S}$-methionine-labeled saponinresistant (SAP) protein fraction of $\mathrm{v}$-ras-transformed renal cells and their NaB-treated counterparts indicated that PAI-1 (both the 50$\mathrm{kD}$ and fully glycosylated $52-\mathrm{kD}$ species) were expressed in $\mathrm{NaB}$ revertants but not in untreated cells (a). PAI-1 from normal kidney cells (NRK) served as a marker. The band above PAI-1 in v-ras cells (at 62-kD) is the heavily-glycosylated forms of osteopontin (a). Northern blotting confirmed the absence of PAI-1 mRNA in v-rastransformants and the restoration of mRNA expression in response to $\mathrm{NaB}$ (b). 2-D electrophoretic mapping of the SAP fraction proteins derived from ${ }^{35} \mathrm{~S}$-methionine-labeled cultures revealed, furthermore, that PAI-1 induction in response to $\mathrm{NaB}$ treatment was rather selective (c). Map positions of the glycosylated PAI1 isoforms are indicated (solid red outlined rectangle). Proteins common between the cell types are highlighted in color (purple circles, red dashed line box, blue ovals indicating vimentin, and phosho-vimentin breakdown products and actin by black arrows) and did not change in abundance despite the significant PAI-1 induction evident in the $\mathrm{v}$-ras $/ \mathrm{NaB}$ protein profile (c). cells in a concentration-dependent manner with an $80 \%$ reduction in final population density after a 5-day exposure to $100 \mathrm{nM}$ PAI-1 (Figure 5(a)). Indeed, the level of growth inhibition in cultures exposed to $20 \mathrm{nM}$ PAI-1 (45\% reduction in population density relative to the corresponding control) (Figure 5(a)) approximated the $47.5 \%$ decrease induced by $10 \mathrm{mM} \mathrm{NaB}$ even in the presence of serum (Figure 4(b)). Ha-ras-transformed HaCaT cells, which express low levels of PAI-1 in response to EGF [33], were also growth inhibited by exposure to PAI-1 14-1B in the presence of FBS or EGF (Figures 5(b) and 5(c)) largely due to $\mathrm{G}_{1}$ arrest (Figure 5(c)). To assess this effect more critically in a genetic context, antisense knockdown (PAI- $\left.{ }^{\mathrm{KD}} ; 4 \mathrm{HH}\right)$ cells (Figure 6(a)), which are resistant to $\mathrm{NaB}$-dependent proliferative inhibition, were incubated in PAI-1-supplemented medium with or without, addition of NaB. Recombinant PAI-1, at a final concentration of $20 \mathrm{nM}$, effectively suppressed PAI- $1^{\mathrm{KD}}$ cell proliferation; the combination of PAI-1 $+\mathrm{NaB}$ did not significantly impact the extent of cytostasis compared to PAI1 alone (Figure 6(b)). Transient vector-driven re-expression of PAI-1 in Rc/CMVPAI v-ras transfectants (Figure 6(a)) similarly reduced cell growth relative to cells transfected with the empty Rc/CMV construct (Figure 6(b)). Mass cultures of Rc/CMVPAI-expressing cells and, in particular, their G418-selected clonal isolates, but not cells transfected with Rc/CMV without the $2.6 \mathrm{~kb}$ PAI-1 cDNA insert, had significant numbers of very well-spread cells (a hallmark of the growth arrest phenotype in renal epithelial cells [14-16]) compared to Rc/CMV populations. The marked reduction in cell proliferation (Figure 6(b)) and increased spreading in Rc/CMVPAI as compared to Rc/CMV transfectants correlated with an approximately 22 -fold increase in PAI-1 expression.

\section{Discussion}

Data mining of microarray and serial analysis of gene expression profiles consistently identified increased PAI-1 levels as characteristic of specific growth arrest states (e.g., [23, 27, $35,36,39,42-46]$ ). Similar to other HDACi-regulated genes, several of which negatively regulate cell cycle progression [10-13], PAI-1 is a particularly relevant candidate as this SERPIN attenuates uPA-/plasmin-dependent growth factor activation and cellular proliferative responses [22, 23], mediates p53-dependent cytostasis [23-26], and is required for TGF- $\beta 1$-mediated antiproliferative responses [27]. In cells expressing activated ras or raf oncogenes, moreover, induced PAI-1 initiates the engagement of a senescencelike phenotype [28-31] while, for those cells that escape ras-induced senescence, the growth arrest program can be "rescued" upon exposure to certain HDACi (e.g., NaB) with concomitant high-level PAI-1 induction [16, 17, 32]. While molecular events underlying NaB-stimulated PAI-1 expression is unclear, $\mathrm{NaB}$ enhances $\mathrm{Smad} 3$ phosphorylation and potentiates TGF- $\beta$-induced PAI- 1 expression [47], concomitant with $\mathrm{NaB}$-induced $\mathrm{G}_{1}$ arrest [48]. Indeed, overexpression of SMAD3 in $\mathrm{v}$-Ha-ras-transformed keratinocytes induced a cytostatic response, stimulated PAI-1 promoter 


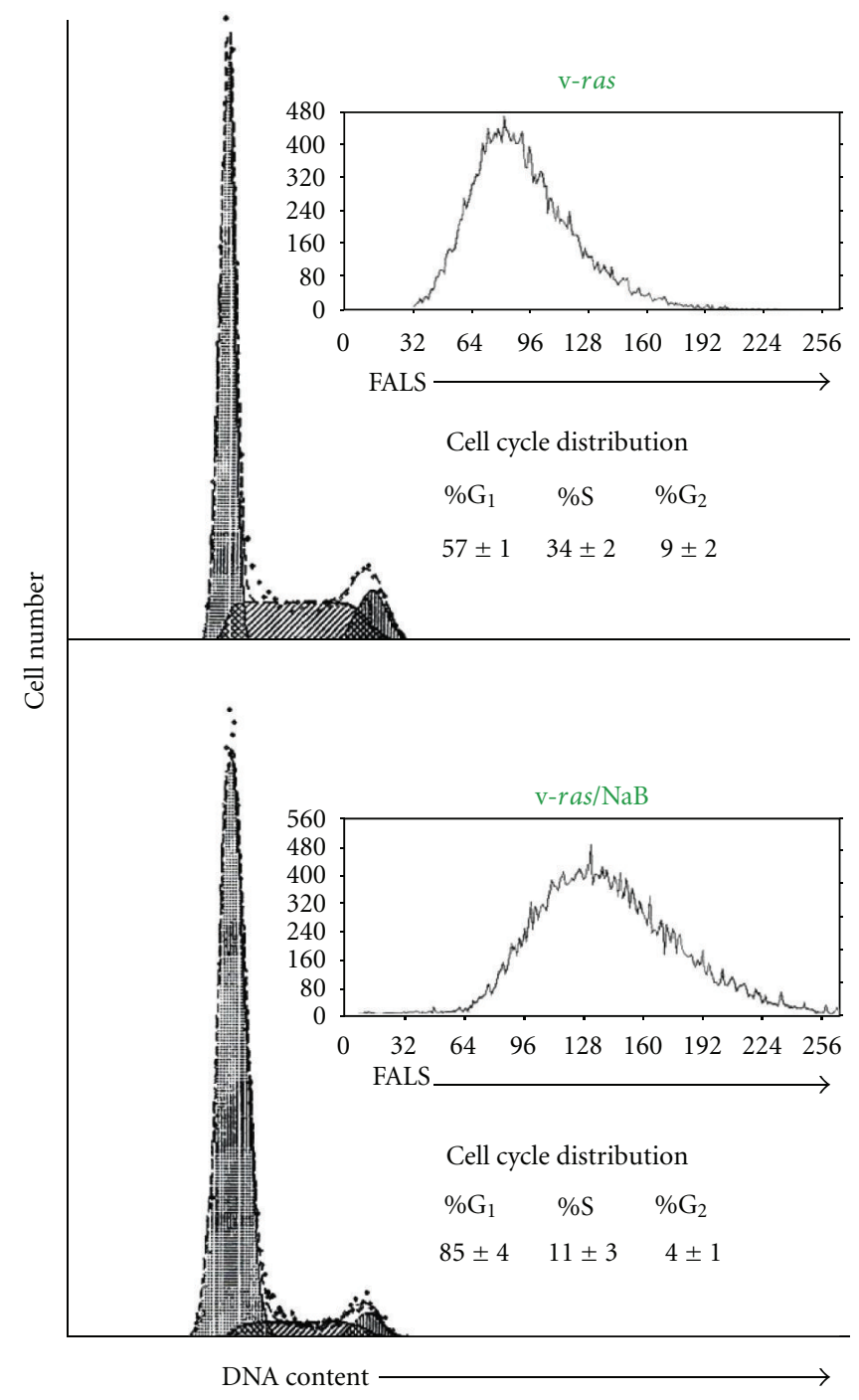

FIGURE 2: Impact of $\mathrm{NaB}$ on cell cycle progression in v-ras transformants. The S-phase fraction of exponentially growing (10\% FBS) cells approximated $>34 \%$ with a tight mean cellular size distribution (mean: channel 80 ) as assessed by forward angle light scatter (FALS) measurements. $\mathrm{NaB}$ treatment resulted in a $\mathrm{G}_{1}$ block (even in FBS-supplemented medium) and a significantly increased mean size.

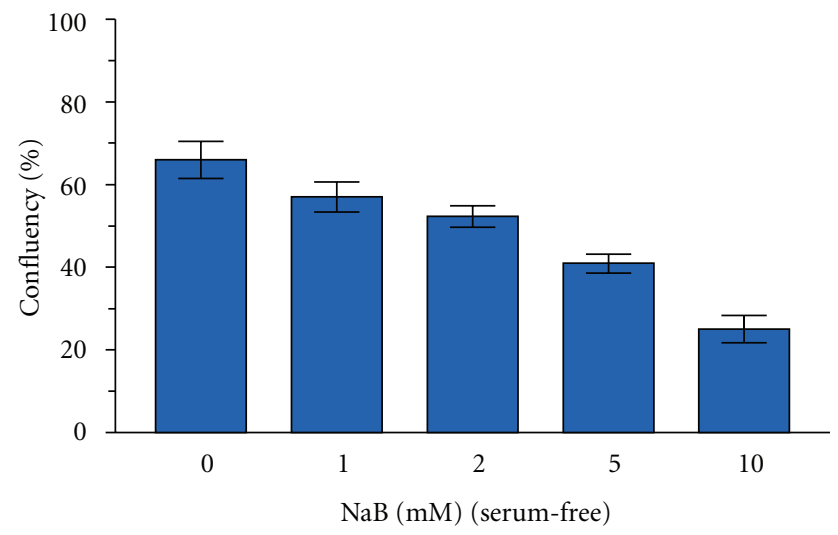

(a)

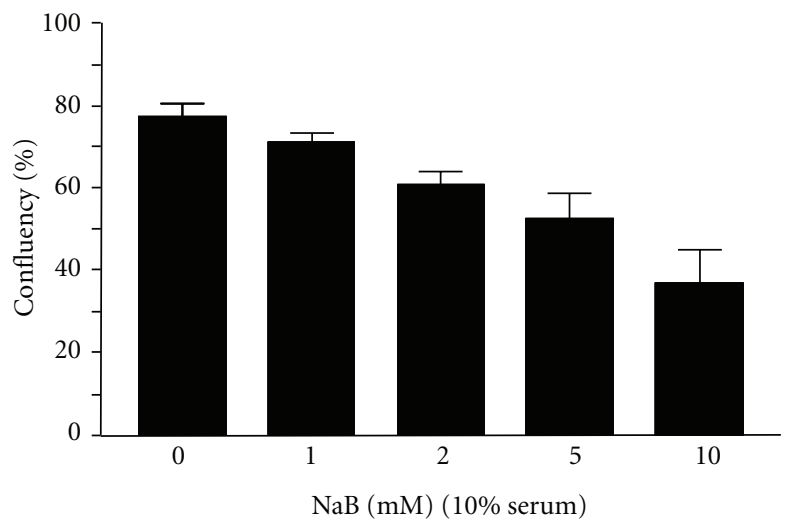

(b)

Figure 3: NaB suppressed cell growth in serum-free or supplemented culture conditions. Proliferative restriction was maximal at $10 \mathrm{mM}$ resulting in final population densities of just $47 \%$ (a) and $52 \%$ (b) compared to respective controls. Data plotted is the mean \pm standard deviation for triplicate assessments of final cell densities (i.e., \% confluency) for each $\mathrm{NaB}$ concentration under the two growth conditions. 

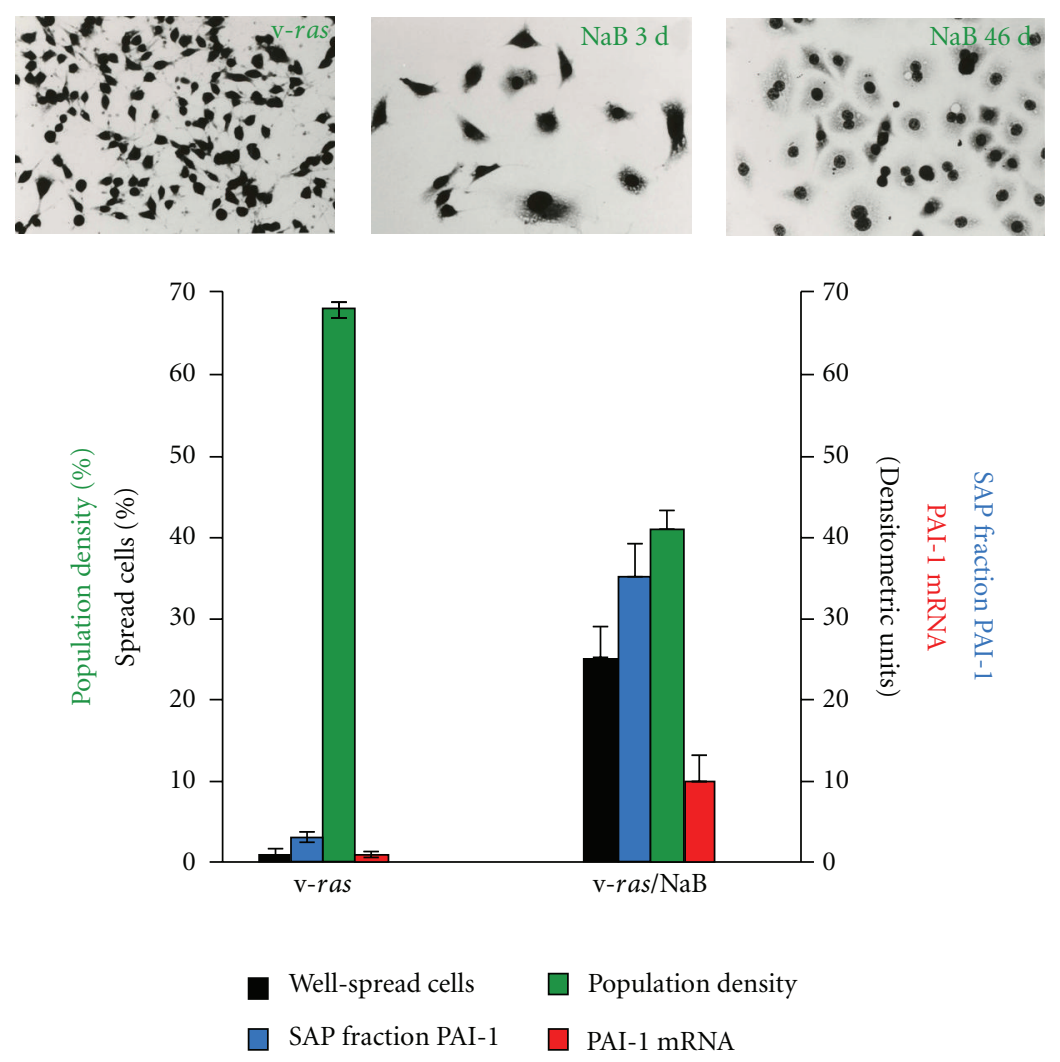

FIGURE 4: Summary characteristics of the NaB-induced phenotype in v-ras-transformed renal epithelial cells. NaB initiated a rapid cytostasis evident within 3 days after exposure with the acquisition of increased cell-spread area consistent with FALS assessment of cell size (i.e., Figure 2). Cells remained growth arrested even after protracted treatment (e.g., 46 days) although such long-term cultures had an increased binucleate frequency. PAI-1 mRNA/protein expression in control populations was low to undetectable in contrast to the levels of PAI-1 transcripts and protein evident in response to $\mathrm{NaB}$. Plots illustrate the mean \pm standard deviation for triplicate assessments for each of the parameters evaluated.

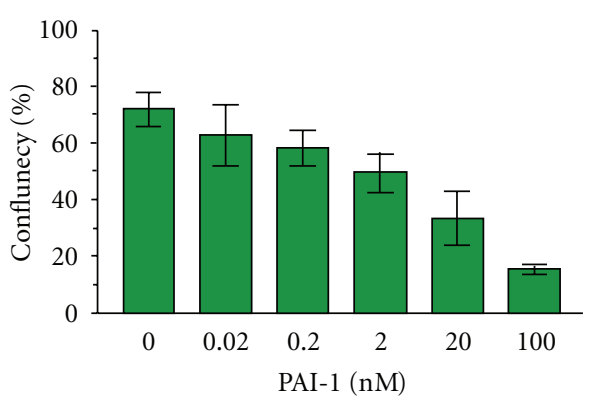

(a)

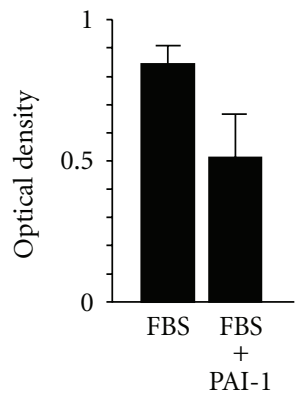

(b)

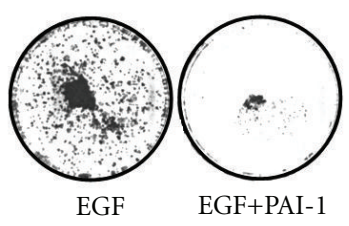

(c)

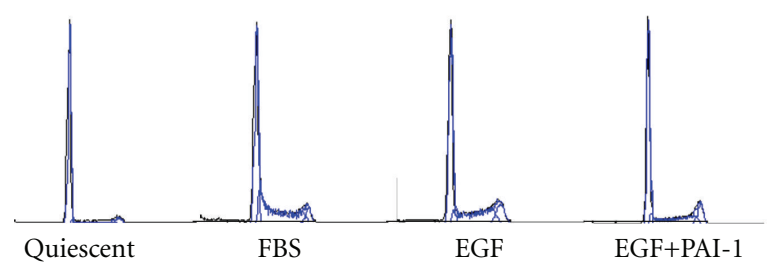

(d)

FIGURE 5: Increasing concentrations of PAI-1 (range 0.02 to $100 \mathrm{nM}$ ) effectively suppressed growth of v-ras-transformants in serum-free (a) as well as serum-supplemented (b) media. In (b), PAI-1 was added to a final level of $20 \mathrm{nM}$. PAI-1 also inhibited EGF-induced HaCaT proliferation, as assessed by crystal violet staining of cells stimulated with EGF $(10 \mathrm{ng} / \mathrm{mL})$ for 5 days in the absence or presence of PAI-1 $(20 \mathrm{nM})(\mathrm{c})$. Growth arrest in EGF-treated HaCaT keratinocytes reflected a PAI-1-induced $\mathrm{G}_{1}$ block evident as early as 24 hours after the addition of PAI-1 compared to the prominent S-phase cohort in FBS- or control EGF-treated cultures (d). Starting quiescent populations (1 day in serum-free medium) were virtually devoid of DNA-synthesizing cells. 

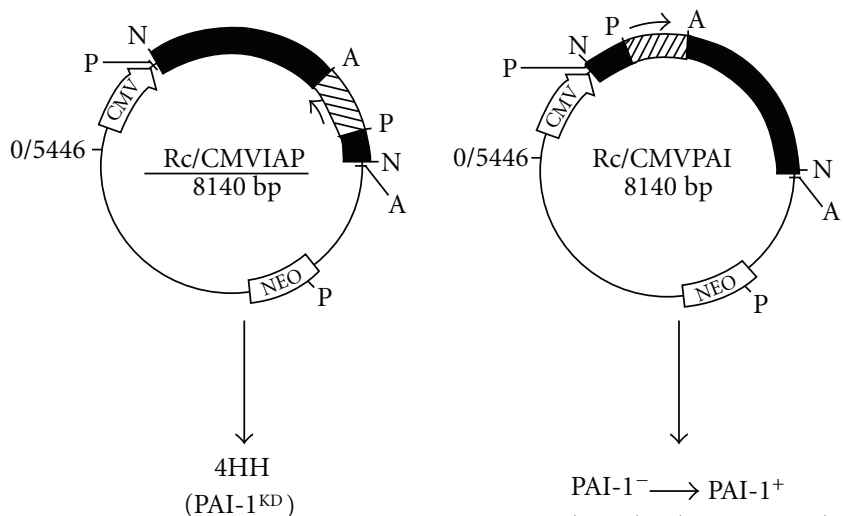

$\mathrm{PAI}-1^{-} \longrightarrow \mathrm{PAI}^{-} 1^{+}$

(v-ras) (Rc/CMVPAI)

(a)

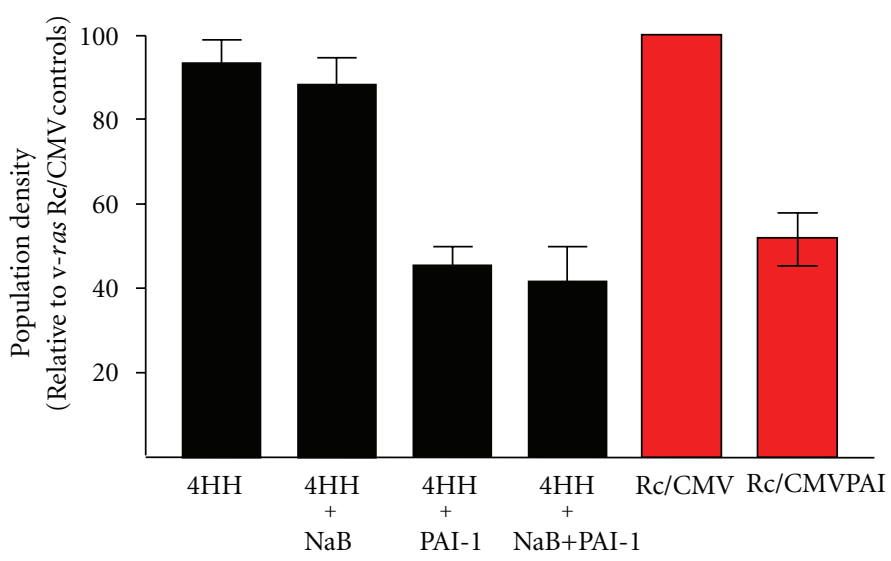

(b)

FIGURE 6: PAI-1 antisense and sense expression vectors were used to generate the PAI-1 knockdown (4HH; PAI- $1^{\mathrm{KD}}$ ) and overexpressing (Rc/CMVPAI) cell lines, respectively, (a). PAI-1-deficient $4 \mathrm{HH}$ cells were resistant to NaB-mediated cytostasis but remained sensitive to PAI-1-induced growth arrest. The combination of NaB+PAI-1 reduced final population densities similar to that of PAI-1 alone cultures (b). Vector-driven PAI-1 overexpression in v-ras transformants also inhibited cell growth consistent with results of the PAI-1 add-back experiments (e.g., Figure 5). Data plotted represents the mean \pm standard deviation for triplicate assessments of final cell densities (i.e., $\%$ confluency).

(3TP-Lux reporter)-dependent transcription, and increased the incidence of senescent epithelial cells [49]. The present findings are consistent with these and previous data that TGF- $\beta$-initiated growth inhibition as well as senescence arrest is PAI-1-dependent $[23,27]$ and establish, moreover, PAI- 1 as a mediator of NaB-initiated cytostasis. Whether this response can be adapted for directed "senescence therapy" of human cancers, remains to be assessed.

$\mathrm{NaB}$ upregulates the cell cycle inhibitors $\mathrm{p} 21^{\mathrm{WAF} 1 / \mathrm{CIP} 1}$ and p16 $6^{\mathrm{INK} 4 \mathrm{~A}}$ in human fibroblasts although targeted disruption of p21 only weakly impacted HDACi-induced senescencelike growth arrest. p53 ${ }^{-/-}$mouse embryo fibroblasts (MEFs), moreover, are resistant to $\mathrm{NaB}$-initiated cytostasis indicating that this tumor suppressor is a major senescence determinant in MEFs [50], and NaB-mediated apoptosis in human melanoma cells is p53-dependent [51]. Indeed, nutlin-3, an MDM2 inhibitor which restores p53 function in tumor cells that retain a wild-type p53, cooperate with several HDACis (including $\mathrm{NaB}$ ) to induce cell death in p53 wild-type tumor cell lines but not in p53-null PC-3 prostatic carcinoma likely by HDACi-induced p53 hyperacetylation and/or MDM2/MDM4 downregulation [52]. This may be dependent, in part, on the extent of increased p53 expression in response to $\mathrm{NaB}$ [53]. Similarly, NaB-stimulated p53 transcriptional activity initiated irreversible $\mathrm{G}_{1} / \mathrm{S}$ cell cycle arrest in c-Ha-ras-transformed rat embryo fibroblasts that were p53 wild-type but not in cells with an inactivated p53 [54]. While the actual contribution of p21 versus INK4A/ARF-encoded genes (e.g., p19) in NaB-induced growth arrest is uncertain $[55,56]$, the role of p53 (at least in MEFs) may be more relevant since p53 is required for PAI-1 expression and growth arrest (see [27, 57]; and Overstreet et al., in preparation). p53 status, therefore, may be a major aspect of HDACi-induced cell cycle arrest through its transcriptional control of PAI-1 and, thereby, PAI-1dependent cytostasis. 


\section{Acknowledgment}

This work was supported by National Institutes of Health Grant GM57242.

\section{References}

[1] R. Marmorstein and S. Y. Roth, "Histone acetyltransferases: function, structure, and catalysis," Current Opinion in Genetics and Development, vol. 11, no. 2, pp. 155-161, 2001.

[2] G. Garcia-Manero and J. P. Issa, "Histone deacetylase inhibitors: a review of their clinical status as antineoplastic agents," Cancer Investigation, vol. 23, no. 7, pp. 635-642, 2005.

[3] S. Y. Roth, J. M. Denu, and C. D. Allis, "Histone acetyltransferases," Annual Review of Biochemistry, vol. 70, pp. 81-120, 2001.

[4] S. Thiagalingam, K. H. Cheng, H. J. Lee, N. Mineva, A. Thiagalingam, and J. F. Ponte, "Histone deacetylases: unique players in shaping the epigenetic histone code," Annals of the New York Academy of Sciences, vol. 983, pp. 84-100, 2003.

[5] W. S. Xu, R. B. Parmigiani, and P. A. Marks, "Histone deacetylase inhibitors: molecular mechanisms of action," Oncogene, vol. 26, no. 37, pp. 5541-5552, 2007.

[6] J. R. Davie, "Inhibition of histone deacetylase activity by butyrate," Journal of Nutrition, vol. 133, no. 7, pp. S2485-S2493, 2003.

[7] J. E. Bolden, M. J. Peart, and R. W. Johnstone, "Anticancer activities of histone deacetylase inhibitors," Nature Reviews Drug Discovery, vol. 5, no. 9, pp. 769-784, 2006.

[8] A. E. Chambers, S. Banerjee, T. Chaplin et al., "Histone acetylation-mediated regulation of genes in leukaemic cells," European Journal of Cancer, vol. 39, no. 8, pp. 1165-1175, 2003.

[9] Y. Sasakawa, Y. Naoe, N. Sogo et al., "Marker genes to predict sensitivity to FK228, a histone deacetylase inhibitor," Biochemical Pharmacology, vol. 69, no. 4, pp. 603-616, 2005.

[10] M. Ocker and R. Schneider-Stock, "Histone deacetylase inhibitors: signalling towards p21 cip1/wafl ," International Journal of Biochemistry and Cell Biology, vol. 39, no. 7-8, pp. 13671374, 2007.

[11] C. van Lint, S. Emiliani, and E. Verdin, "The expression of a small fraction of cellular genes is changed in response to histone hyperacetylation," Gene Expression, vol. 5, no. 4-5, pp. 245-253, 1996.

[12] K. B. Glaser, M. J. Staver, J. F. Waring, J. Stender, R. G. Ulrich, and S. K. Davidsen, "Gene expression profiling of multiple histone deacetylase (HDAC) inhibitors: defining a common gene set produced by HDAC inhibition in T24 and MDA carcinoma cell lines," Molecular Cancer Therapeutics, vol. 2, no. 2, pp. 151-163, 2003.

[13] A. L. Gartel and S. K. Radhakrishnan, "Lost in transcription: p21 repression, mechanisms, and consequences," Cancer Research, vol. 65, no. 10, pp. 3980-3985, 2005.

[14] M. P. Ryan and P. J. Higgins, "Sodium-n-butyrate induces secretion and substrate accumulation of p52 in Kirsten sarcoma virus-transformed rat kidney fibroblasts," International Journal of Biochemistry, vol. 21, no. 1, pp. 31-37, 1989.

[15] P. J. Higgins and M. P. Ryan, "P52(PAI-1) and actin expression in butyrate-induced flat revertants of v-ras-transformed rat kidney cells," Biochemical Journal, vol. 279, no. 3, pp. 883-890, 1991.

[16] P. J. Higgins, P. Chaudhari, and M. P. Ryan, "Cell-shape regulation and matrix protein p52 content in phenotypic variants of ras-transformed rat kidney fibroblasts. Functional analysis and biochemical comparison of p52 with proteins implicated in cell-shape determination," Biochemical Journal, vol. 273, no. 3, pp. 651-658, 1991.

[17] J. M. Mariadason, G. A. Corner, and L. H. Augenlicht, "Genetic reprogramming in pathways of colonic cell maturation induced by short chain fatty acids: comparison with trichostatin A, sulindac, and curcumin and implications for chemoprevention of colon cancer," Cancer Research, vol. 60, no. 16, pp. 4561-4572, 2000.

[18] T. Chiba, O. Yokosuka, M. Arai et al., "Identification of genes up-regulated by histone deacetylase inhibition with cDNA microarray and exploration of epigenetic alterations on hepatoma cells," Journal of Hepatology, vol. 41, no. 3, pp. 436-445, 2004.

[19] K. Wakabayashi, H. Saito, F. Kaneko, N. Nakamoto, S. Tada, and T. Hibi, "Gene expression associated with the decrease in malignant phenotype of human liver cancer cells following stimulation with a histone deacetylase inhibitor," International Journal of Oncology, vol. 26, no. 1, pp. 233-239, 2005.

[20] Y. Tabuchi, I. Takasaki, T. Doi, Y. Ishii, H. Sakai, and T. Kondo, "Genetic networks responsive to sodium butyrate in colonic epithelial cells,” FEBS Letters, vol. 580, no. 13, pp. 3035-3041, 2006.

[21] M. Ocker and R. Schneider-Stock, "Histone deacetylase inhibitors: signalling towards p $21^{\text {cip } 1 / \text { wafl }}$, International Journal of Biochemistry and Cell Biology, vol. 39, no. 7-8, pp. 13671374, 2007.

[22] C. E. Wilkins-Port, Q. Ye, J. E. Mazurkiewicz, and P. J. Higgins, "TGF- $\beta 1+$ EGF-initiated invasive potential in transformed human keratinocytes is coupled to a plasmin/mmp-10/mmp1-dependent collagen remodeling axis: role for PAI-1," Cancer Research, vol. 69, no. 9, pp. 4081-4091, 2009.

[23] R. M. Kortlever, P. J. Higgins, and R. Bernards, "Plasminogen activator inhibitor-1 is a critical downstream target of p53 in the induction of replicative senescence," Nature Cell Biology, vol. 8, no. 8, pp. 878-884, 2006.

[24] L. E. Klein, B. S. Freeze, A. B. Smith, and S. B. Horwitz, "The microtubule stabilizing agent discodermolide is a potent inducer of accelerated cell senescence," Cell Cycle, vol. 4, no. 3, pp. 501-507, 2005.

[25] H. Ota, E. Tokunaga, K. Chang et al., "Sirt1 inhibitor, Sirtinol, induces senescence-like growth arrest with attenuated rasMAPK signaling in human cancer cells," Oncogene, vol. 25, no. 2, pp. 176-185, 2006.

[26] C. A. Schmitt, J. S. Fridman, M. Yang et al., "A senescence program controlled by $\mathrm{p} 53$ and $\mathrm{p} 16^{\mathrm{INK} 4 \mathrm{a}}$ contributes to the outcome of cancer therapy," Cell, vol. 109, no. 3, pp. 335-346, 2002.

[27] R. M. Kortlever, J. H. Nijwening, and R. Bernards, “Transforming growth factor- $\beta$ requires its target plasminogen activator inhibitor-1 for cytostatic activity," Journal of Biological Chemistry, vol. 283, no. 36, pp. 24308-24313, 2008.

[28] D. X. Mason, T. J. Jackson, and A. W. Lin, "Molecular signature of oncogenic ras-induced senescence," Oncogene, vol. 23, no. 57, pp. 9238-9246, 2004.

[29] M. Serrano, A. W. Lin, M. E. McCurrach, D. Beach, and S. W. Lowe, "Oncogenic ras provokes premature cell senescence associated with accumulation of $\mathrm{p} 53$ and $\mathrm{p} 16^{\mathrm{INK4a}}$," Cell, vol. 88, no. 5, pp. 593-602, 1997.

[30] V. G. Gorgoulis and T. D. Halazonetis, "Oncogene-induced senescence: the bright and dark side of the response," Current Opinion in Cell Biology, vol. 22, no. 6, pp. 816-827, 2010. 
[31] V. L. Gabai, J. A. Yaglom, T. Waldman, and M. Y. Sherman, "Heat shock protein Hsp72 controls oncogene-induced senescence pathways in cancer cells," Molecular and Cellular Biology, vol. 29, no. 2, pp. 559-569, 2009.

[32] P. J. Higgins, M. P. Ryan, and D. M. Jelley, "p52 $2^{\text {PAI-1 }}$ gene expression in butyrate-induced flat revertants of v-ras-transformed rat kidney cells: mechanism of induction and involvement in the morphological response," Biochemical Journal, vol. 321, no. 2, pp. 431-437, 1997.

[33] M. B. Berkenpas, D. A. Lawrence, and D. Ginsburg, "Molecular evolution of plasminogen activator inhibitor-1 functional stability," EMBO Journal, vol. 14, no. 13, pp. 2969-2977, 1995.

[34] K. M. Providence, S. M. Kutz, L. Staiano-Coico, and P. J. Higgins, "PAI-1 gene expression is regionally induced in wounded epithelial cell monolayers and required for injury repair," Journal of Cellular Physiology, vol. 182, no. 2, pp. 269-280, 2000.

[35] P. J. Higgins and M. P. Ryan, "Biochemical localization of the transformation-sensitive $52 \mathrm{kDa}$ p52 protein to the substratum contact regions of cultured rat fibroblasts. Butyrate induction, characterization, and quantification of p52 in vras transformed cells," Biochemical Journal, vol. 257, no. 1, pp. 173-182, 1989.

[36] M. P. Ryan and P. J. Higgins, "Cytoarchitecture of Kirsten sarcoma virus-transformed rat kidney fibroblasts: butyrateinduced reorganization within the actin microfilament network," Journal of Cellular Physiology, vol. 137, no. 1, pp. 25-34, 1988.

[37] P. J. Higgins and T. J. Smith, "Pleotrophic action of interferon gamma in human orbital fibroblasts," Biochimica et Biophysica Acta, vol. 1181, no. 1, pp. 23-30, 1993.

[38] P. J. Higgins, M. P. Ryan, R. Zehab, T. D. Gelehrter, and P. Chaudhari, "p52 Induction by cytochalasin D in rat kidney fibroblasts: homologies between p52 and plasminogen activator inhibitor type-1," Journal of Cellular Physiology, vol. 143, no. 2, pp. 321-329, 1990.

[39] P. J. Higgins, M. P. Ryan, and A. Ahmed, "Cell-shape-associated transcriptional activation of the p52(PAI-1)gene in rat kidney cells," Biochemical Journal, vol. 288, no. 3, pp. 10171024, 1992.

[40] P. Yaswen and J. Campisi, "Oncogene-induced senescence pathways weave an intricate tapestry," Cell, vol. 128, no. 2, pp. 233-234, 2007.

[41] A. Kilbey, A. Terry, E. R. Cameron, and J. C. Neil, "Oncogeneinduced senescence: an essential role for Runx," Cell Cycle, vol. 7, no. 15, pp. 2333-2340, 2008.

[42] D. N. Shelton, E. Chang, P. S. Whittier, D. Choi, and W. D. Funk, "Microarray analysis of replicative senescence," Current Biology, vol. 9, no. 17, pp. 939-945, 1999.

[43] G. Untergasser, H. B. Koch, A. Menssen, and H. Hermeking, "Characterization of epithelial senescence by serial analysis of gene expression: identification of genes potentially involved in prostate cancer," Cancer Research, vol. 62, no. 21, pp. 62556262, 2002.

[44] A. L. Fridman and M. A. Tainsky, "Critical pathways in cellular senescence and immortalization revealed by gene expression profiling," Oncogene, vol. 27, no. 46, pp. 5975-5987, 2008.

[45] J. Freytag, C. E. Wilkins-Port, C. E. Higgins et al., "PAI-1 regulates the invasive phenotype in human cutaneous squamous cell carcinoma," Journal of Oncology, vol. 2009, Article ID 963209, 12 pages, 2009.

[46] J. Freytag, C. E. Wilkins-Port, C. E. Higgins, S. P. Higgins, R. Samarakoon, and P. J. Higgins, "PAI-1 mediates the TGF$\beta 1+$ EGF-induced "scatter" response in transformed human keratinocytes," Journal of Investigative Dermatology, vol. 130, no. 9, pp. 2179-2190, 2010.

[47] K. A. Nguyen, Y. Cao, J. R. Chen, C. M. Townsend, and T. C. Ko, "Dietary fiber enhances a tumor suppressor signaling pathway in the gut," Annals of Surgery, vol. 243, no. 5, pp. 619627, 2006.

[48] B. Pajak, A. Orzechowski, and B. Gajkowska, "Molecular basis of sodium butyrate-dependent proapoptotic activity in cancer cells," Advances in Medical Sciences, vol. 52, pp. 83-88, 2007.

[49] K. Vijayachandra, J. Lee, and A. B. Glick, "Smad3 regulates senescence and malignant conversion in a mouse multistage skin carcinogenesis model," Cancer Research, vol. 63, no. 13, pp. 3447-3452, 2003.

[50] J. Munro, N. I. Barr, H. Ireland, V. Morrison, and E. K. Parkinson, "Histone deacetylase inhibitors induce a senescence-like state in human cells by a p16-dependent mechanism that is independent of a mitotic clock," Experimental Cell Research, vol. 295, no. 2, pp. 525-538, 2004.

[51] D. Bandyopadhyay, A. Mishra, and E. E. Medrano, "Overexpression of histone deacetylase 1 confers resistance to sodium butyrate-mediated apoptosis in melanoma cells through a p53-mediated pathway," Cancer Research, vol. 64, no. 21, pp. 7706-7710, 2004.

[52] C. D. Palani, J. F. Beck, and J. Sonnemann, "Histone deacetylase inhibitors enhance the anticancer activity of nutlin-3 and induce p53 hyperacetylation and downregulation of MDM2 and MDM4 gene expression," Investigational New Drugs. In press.

[53] J. Joseph, N. Wajapeyee, and K. Somasundaram, "Role of p53 status in chemosensitivity determination of cancer cells against histone deacetylase inhibitor sodium butyrate," International Journal of Cancer, vol. 115, no. 1, pp. 11-18, 2005.

[54] E. I. Bukreeva, N. D. Aksenov, A. A. Bardin, V. A. Pospelov, and T. V. Pospelova, "Effect of histone deacetylase inhibitor sodium butyrate $(\mathrm{NaB})$ on transformants $\mathrm{E} 1 \mathrm{~A}+\mathrm{cHa}$-ras expressing wild type p53 with suppressed transactivation function," Tsitologiia, vol. 3, no. 5, pp. 697-705, 2009.

[55] A. Matheu, P. Klatt, and M. Serrano, "Regulation of the INK4a/ARF locus by histone deacetylase inhibitors," Journal of Biological Chemistry, vol. 280, no. 51, pp. 42433-42441, 2005.

[56] Y. F. Wang, N. S. Chen, Y. P. Chung, L. H. Chang, Y. H. Chiou, and C. Y. Chen, "Sodium butyrate induces apoptosis and cell cycle arrest in primary effusion lymphoma cells independently of oxidative stress and $\mathrm{p} 21^{\text {cip1/wafl }}$ induction," Molecular and Cellular Biochemistry, vol. 285, no. 1-2, pp. 51-59, 2006.

[57] R. M. Kortlever and R. Bernards, "Senescence, wound healing and cancer: the PAI-1 connection," Cell Cycle, vol. 5, no. 23, pp. 2697-2703, 2006. 

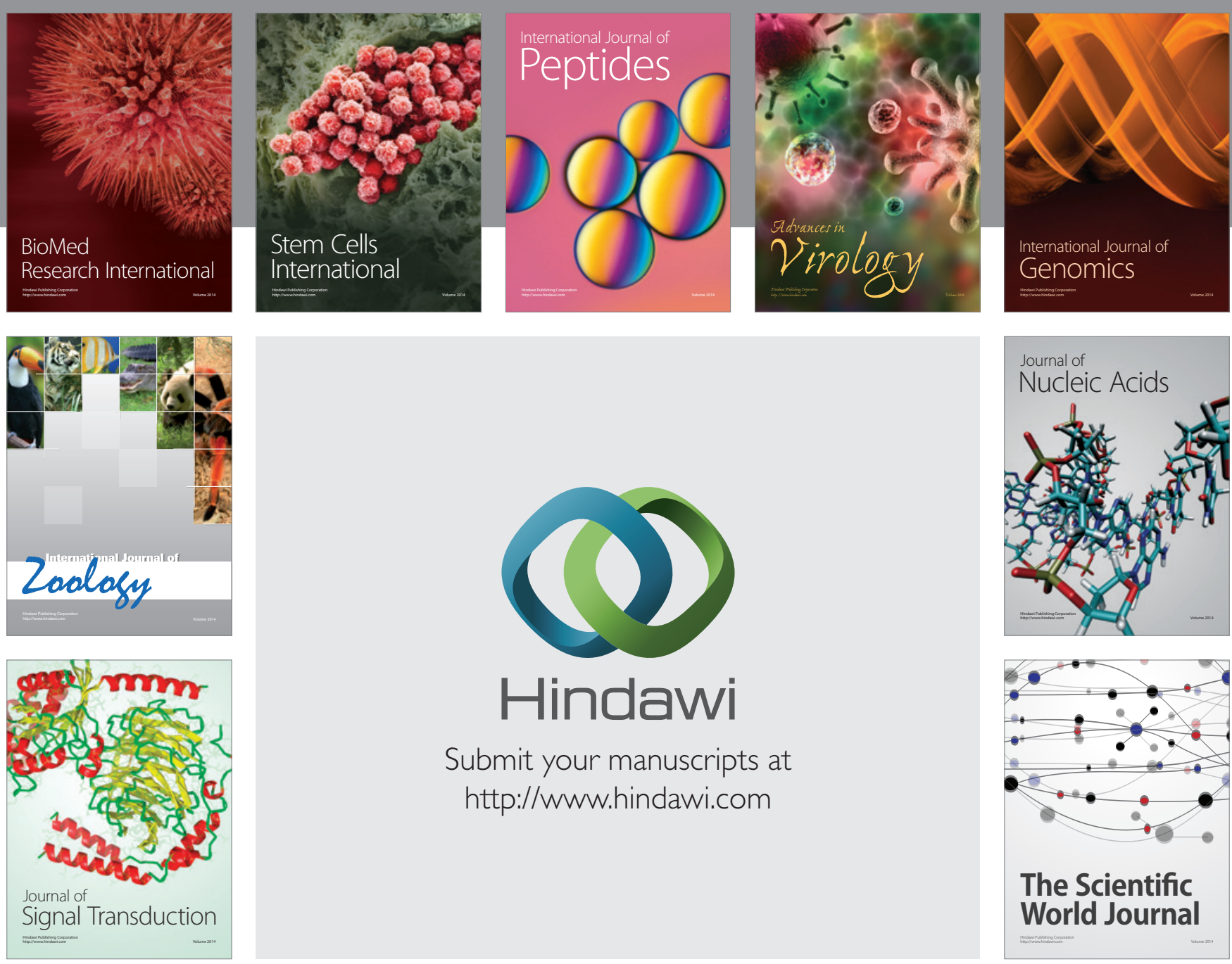

Submit your manuscripts at

http://www.hindawi.com
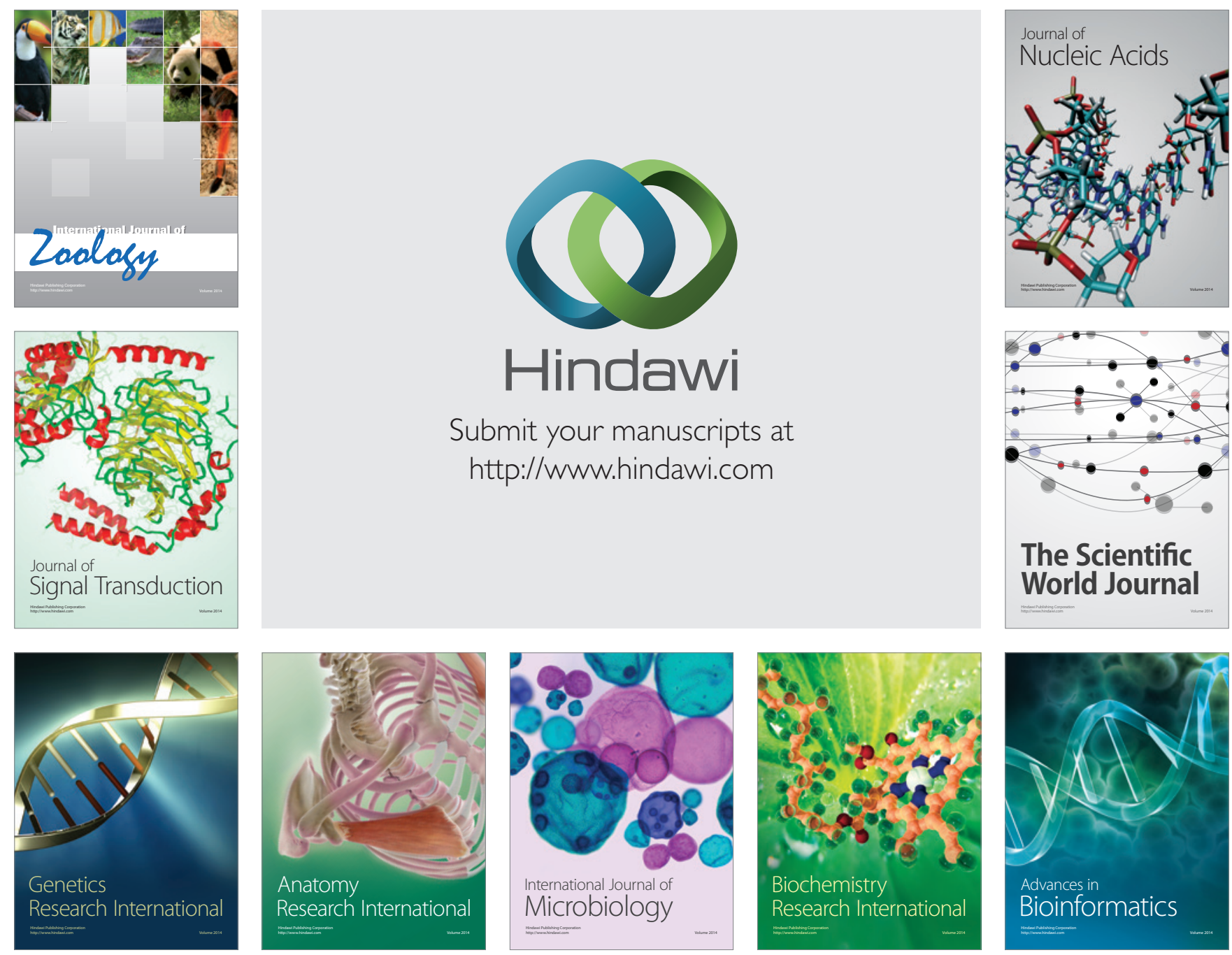

The Scientific World Journal
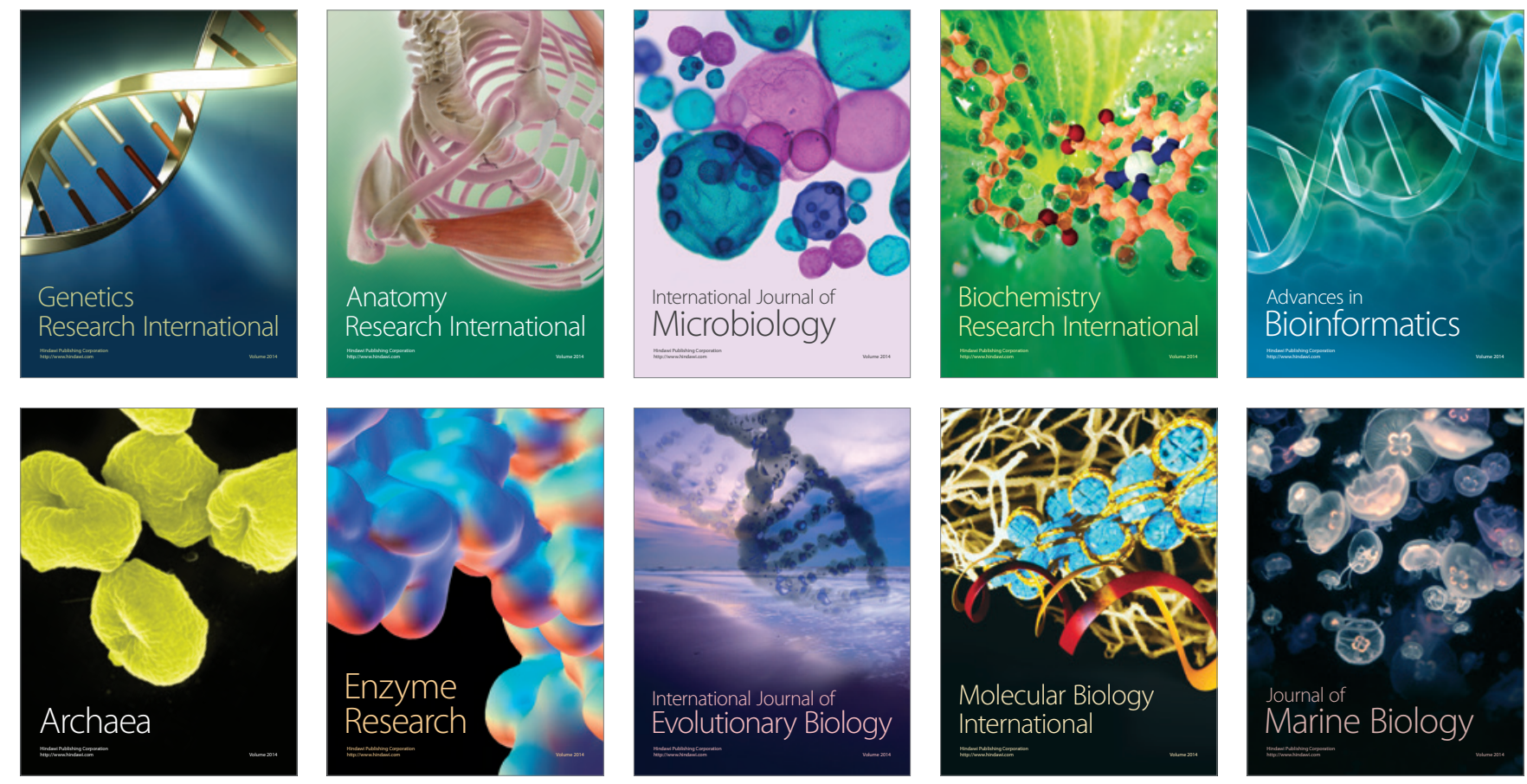